\title{
Geographical distribution and alternate hosts of Striga gesnerioides (Willd.) Vatke in Burkina Faso
}

\author{
Pingawindé SAWADOGO1, T. Benoit Joseph BATIENO2, Zakaria DIENI², Nerbéwendé SAWADOGO1, \\ Tinga Jeremy OUEDRAOGO2 and Mahamadou SAWADOGO1 \\ 1 Université Joseph KI-ZERBO, UFR/SVT, Laboratoire Biosciences / Equipe de Recherche Génétique et \\ Amélioration des plantes BP 7021, Ouagadougou 03 Burkina Faso; \\ 2 Institut de l'Environnement et de Recherches Agricoles (INERA) CREAF de Kamboinsé, Département de \\ Productions Végétale BP 7047, Ouagadougou 03 Burkina Faso
}

Original submitted in on $5^{\text {th }}$ November 2019. Published online at www.m.elewa.org/journals/ on $31^{\text {st }}$ January 2020 https://doi.org/10.35759/JABs.145.10

\begin{abstract}
Objective: Striga gesnerioides (Willd.) Vatke is one of the most important parasitic weeds affecting cowpea production in Burkina Faso. This study was designed to establish a clear geographic distribution of Striga gesnerioides and identifies its alternate hosts in Burkina Faso:

Methodology and Results: A prospection was undertaken in all parts the country. A minimum distance of 25 $\mathrm{km}$ was observed between sampling sites. The sampling sites were mainly naturally Striga infested fields and fallows. The results showed that Striga gesnerioides is found to be parasitizing cowpea and other alternate hosts in the four phytogeographical sectors of the country. However, the degree of infestation increases from the South to the North. During the prospection, five (05) weeds species were identified as alternate hosts of $S$. gesnerioides. These were Cassia mimosoides, Alysicarpus ovalifolius, Ipomea eriocarpa, Ipomea sp, and Thephrosia pedicellata. In addition, four (04) morphotypes of Striga gesnerioides were all found to be parasitizing both wild plants and cowpea (Vigna unguiculata).

Conclusion and application of results: From these results, a genetic diversity study can be undertaken in order to determine the intraspecific genetic variability within Striga gesnerioides in Burkina Faso. This could allow a clear identification and mapping of the different races of Striga occurring in the country. The determination of the geographic distribution of the different races will facilitate the adoption of new strategies for controlling Striga.
\end{abstract}

Key words: Burkina Faso, geographical distribution, morphotypes, Striga gesnerioides, alternate host,

\section{INTRODUCTION}

The Striga is an epirhizal parasitic phanerogam from the family of Scrophulariaceae well known in tropical Africa because of its damage on the host crops (Boussim, 2002). It is a major constraint hindering the achievement food security. The gradual agronomic consequence of Striga attack is the reduction of crop yields, total yield loss and the abandonment of arable lands (Sallé and RaynalRoques; 1989; Hoffman et al., 1997; Ifoam, 2007). Except Striga euphrasioides (Ramaiah et al., 1983), the Striga species are unable to complete their biological cycle in the absence of an herbaceous angiosperm (Raynal-Roques, 1993). In Burkina Faso, 13 species of Striga have been 
identified across the country (Boussim et al., 2011). Among these species Striga hermonthica and Striga gesnerioides constitute to the two economical important species in the country (Boussim et al., 2011). Striga gesnerioides is widespread in the semi-arid regions of Africa and is one of the two best-known Striga species in Burkina Faso in relation to the importance of the attacked crops. It infests a wide range of plants families among which the Fabaceae, Convolvulaceae, Euphorbiaceae and Solanaceae families (Sallé et al., 1995; Hibberd et al., 1996; Wade, 2000; Botanga and Timko, 2005; Koga et al., 2017). It's most important hosts crops are cowpea, tobacco and sweet potato (Sallé et al., 1995; Berner and Williams 1998; Koga et al., 2018). In terms of yield loss, the Striga gesnerioides is a major biotic constraint for the cowpea producers in Burkina Faso. According to (Sallé, 2002 and Langyintuo et al., 2003) yield loss

\section{MATERIALS AND METHODS}

Presentation of the study area: The Burkina Faso, situated between the $9^{\text {th }}$ and $15^{\text {th }}$ parallels of northern latitude, is a landlocked country of West Africa. It is divided into thirteen (13) regions and forty-five (45) provinces and has an area of $274,000 \mathrm{~km}^{2}$. According to the last general census of the population carried out in 2006 , more than $80 \%$ of the population lives in rural area (INSD, 2009). Its geography is unevenly distributed on the territory, the northern zone is very desert and it degrades into savannah as one goes down towards the south. The climate is of the SudanoSahelian type, characterized by an alternation of a dry season and a rainy season. The duration of winter time is increasing from north to south (Zoungrana, 1991; Ibrahim et al., 2012). The study overcast all thirteen (13) administrative regions and different agroclimatic regions of Burkina Faso.

Field prospecting and collection of seeds of Striga gesnerioides: A prospection and collection of Striga gesnerioides seeds was done all-over the country from

\section{RESULTS}

Geographic distribution of Striga gesnerioides in Burkina Faso: The area of agroecological distribution of Striga gesnerioides covers the four (04) phytogeographic sectors of Burkina Faso. The Field visits allowed to observation of the degree of infestation due to this parasite vary between 50 and $85 \%$. Given the contribution of cowpea in the fight against hunger and poverty in sub-Saharan Africa and particularly in Burkina Faso, studies have been conducted to limit yield losses due to Striga gesnerioides (Ouédraogo, 2001; Tignegré, 2010; Ouédraogo et al., 2012). However, because of the wide ecological plasticity and the intraspecific variability of the parasite, its noxious effects persist. Worse, it continues to spread and colonize new agricultural areas that were free of Striga gesneioides infestation. Therefore, knowing the actual extent and the geographical distribution of Striga gesnerioides infestations is necessary for breeding and deploying new resistant varieties for a more efficient control of the weed. This study aimed at establishing the geographical distribution of Striga gesnerioides, identifying the morphotypes and its potential hosts plants in Burkina Faso.

September to October in 2017 and 2018. It was carried out according to transects chosen according to the main roads of the country and also taking into account the agroecological zones where Striga gesnerioides occurs (Ouédraogo, 2001; Tignégré, 2010). A minimum distance of $25 \mathrm{~km}$ was observed between sampling sites. The sampling sites were mainly fields and fallows characterized by natural parasitic infestation. GPS (mark GARMIN) coordinates of each collection site was recorded. On the survey and collection transects, the different Striga morphotypes have been identified.

Data analysis: The GPS coordinates were used to generate agroecological distribution map of Striga gesnerioides with arcGis 10.3 software. The identification of Striga gesnerioides wild hosts was done in collaboration with a botanist using the illustrated flora of Senegal. The description of Striga gesnerioides morphotypes was carry out by visual observation.

of the fields, the collection of Striga gesnerioides seeds and samples for DNA extraction. Thus, samples of Striga gesnerioides were collected in all phytogeographic domains. This study found that the Cascades region is characterized by a low infestation 
unlike other regions where Striga gesnerioides pressure is very high in the cowpea fields. The degree of infestation of the fields is increasing from south to north. In the Sahelian and northern phytogeographical zones, the infestation density is high on coarse and rocky soils as well as on the others types of soils. The same observation was made in the localities of Zecco, Saro,
Léo, Koumbia, Pâ and Satiri located in the South Sudan phytogeographic sector. On the contrary, in the localities of Dano, Gaoua, Kampti and Bama, the degree of infestation is also high, but the presence of Striga gesneroides is much more concentrated on coarse-textured soils and rocky outcrops (see photo $n^{\circ}$ 1).

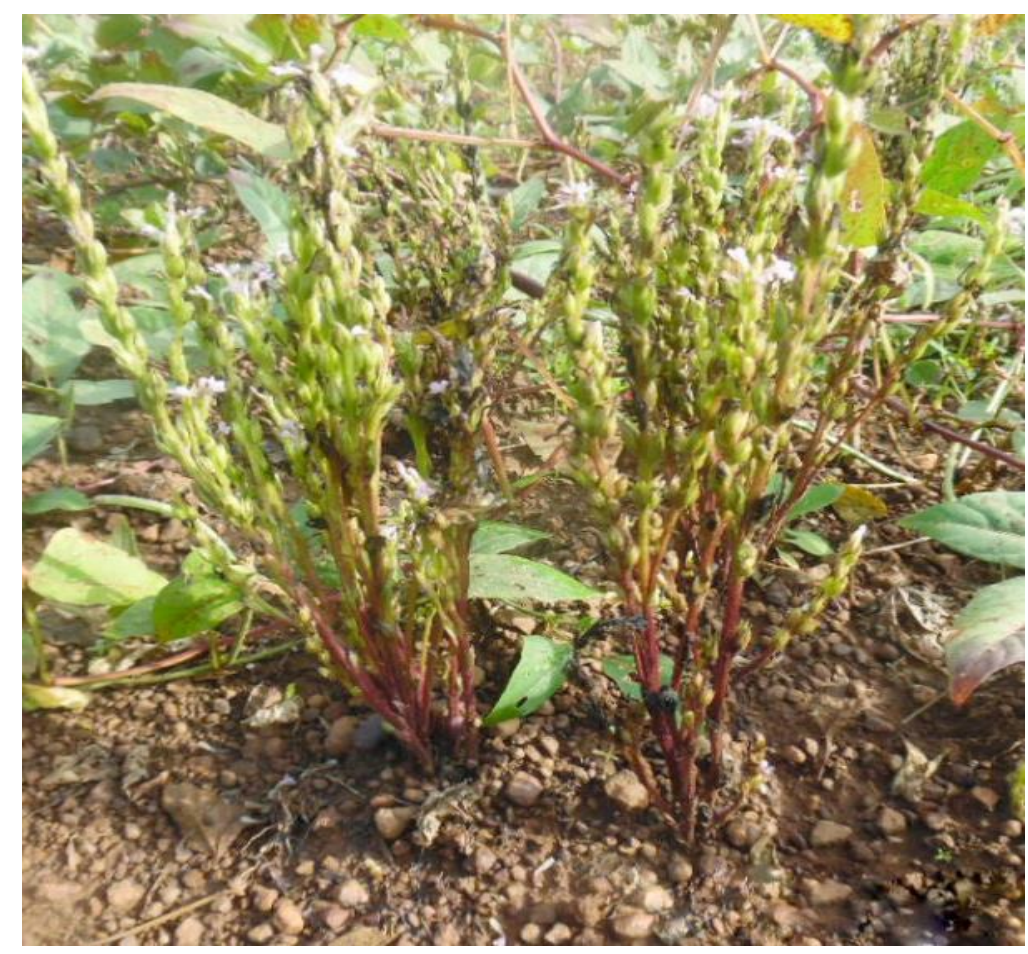

Photo 1: Striga gesnerioides on coarse textured soil.

In Toussiana and Niangoloko the presence of the parasite was mainly observed in coarse textured soils and rocky outcrops. The degree of infestation of cowpea fields by Striga gesnerioides in this part was the lowest compared to the rest of the country. In both localities, the degree of infestation was low to constitute a threat to cowpea production. The zonation of the geographical distribution of Striga gesnerioides across the country is illustrated in Figure 1 below. 


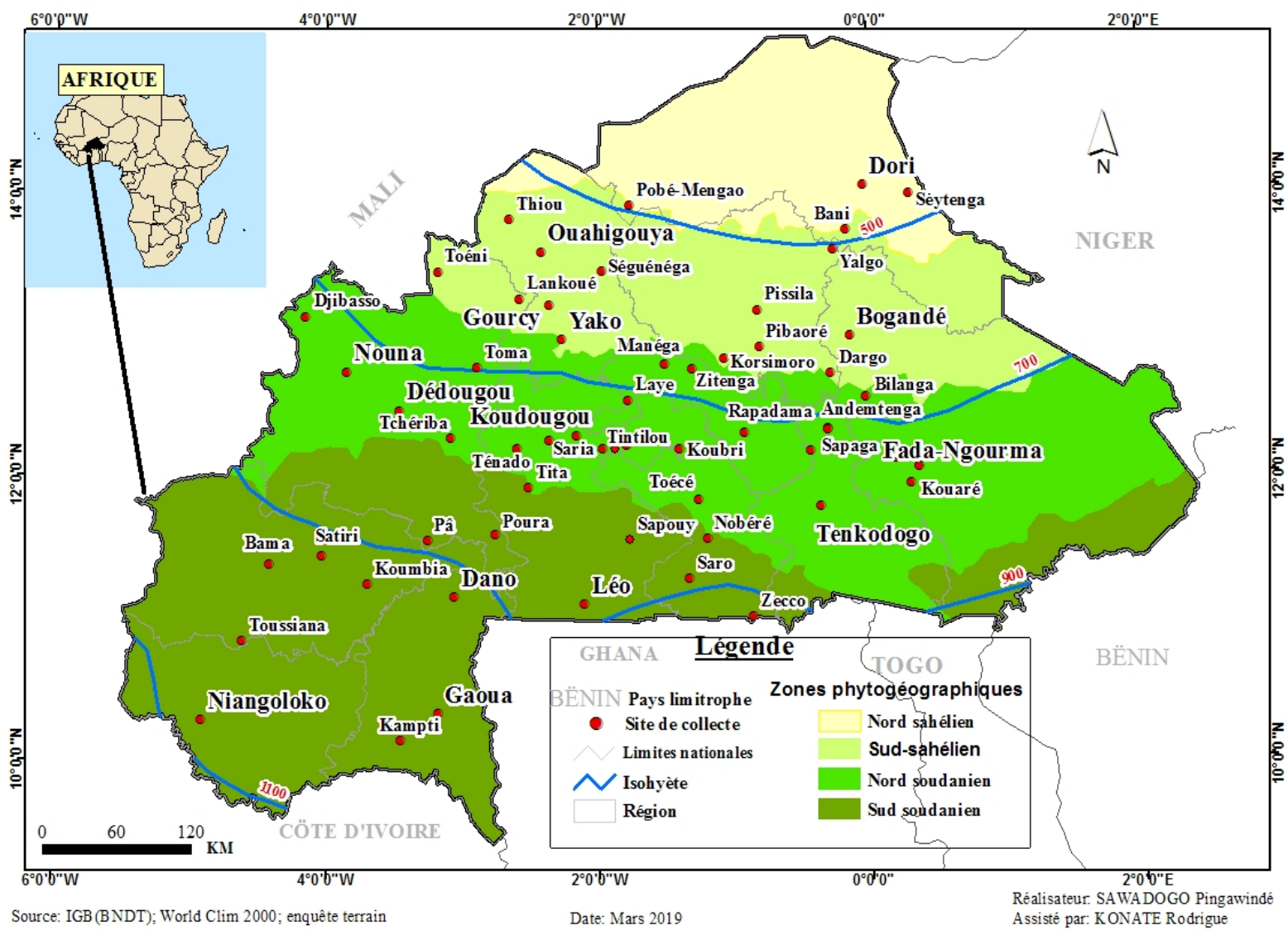

Figure 1: map of geographical distribution of Striga gesnerioides in Burkina Faso

Morphotype of Striga gesnerioides: During the collection, four (04) morphotypes of Striga gesnerioides were identified based on flowers and stems coloration: morphotype with green stem and white flowers; morphotype with a green stem and purple flowers, morphotype with a red stem and reddish flowers, and finally the morphotype with a green-purple stem, which is the most common morphotype on the cowpea (Photo
$2,3,4,5)$. The morphotype found mainly on cowpea is distinguished by a more abundant vegetative development, especially the size and abundance of the branches of the stem; it is also characterized by a variegated coloration of the stem and white-purple or purple for the flowers. The morphotype with reddish stem was observed in Niangoloko on the cowpea whilst in Gaoua and Dano it was observed on wild hosts. 


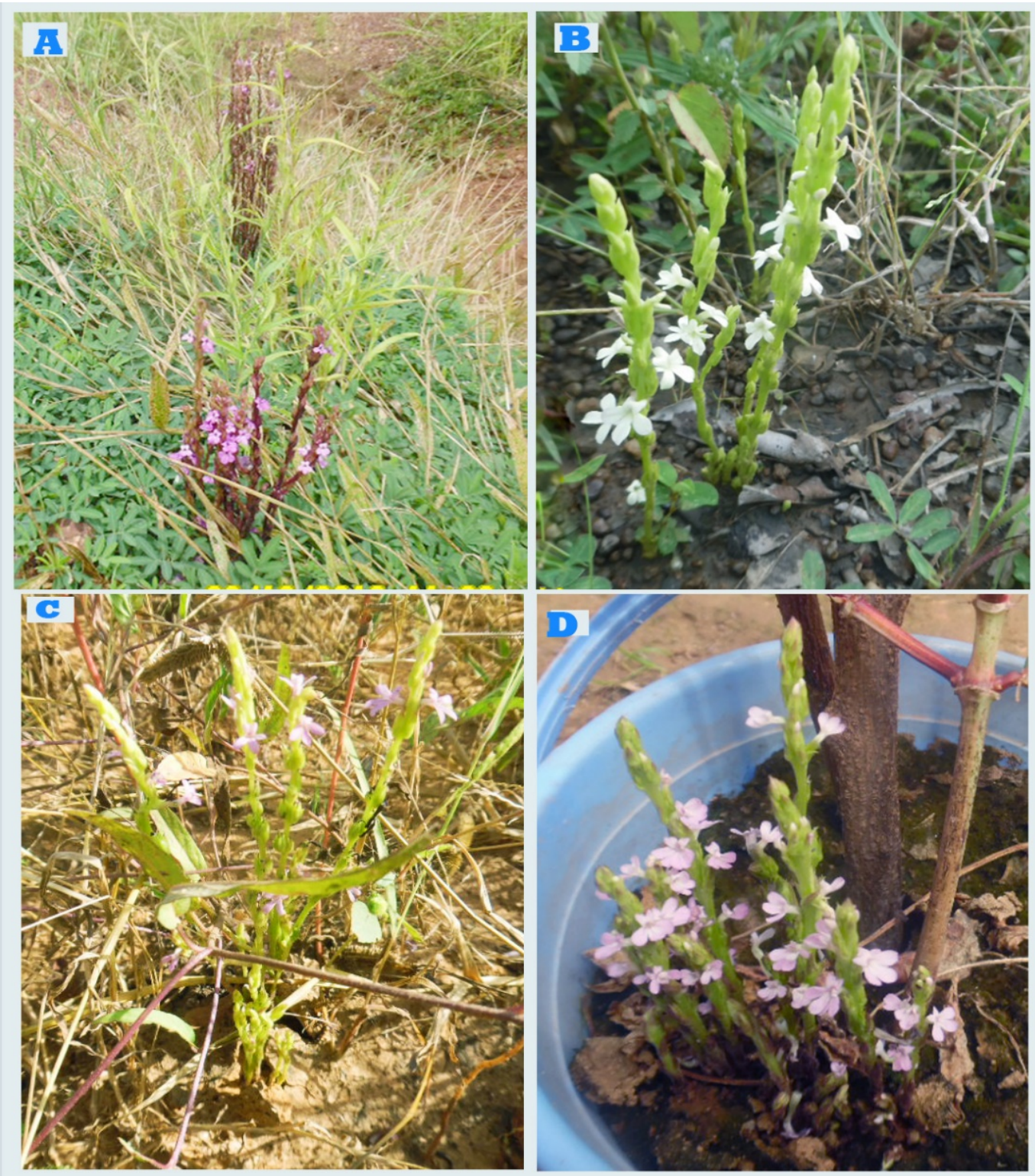

Photo2: Morphotype of Striga gesnerioides (A) Red stems with reddish flowers at Gaoua; (B) Green stem with white flowers at Dano; (C) green stem and purple flower at Thiou; (D) variegated stalk and purple flower

Some wild hosts of Striga gesnerioides: Five (05) wild species have been identified in fallow land as hosts of Striga gesnerioides in the localities of Thiou, Gaoua,
Dano and Seytenga. The names of these species and the families to which they belong are shown in Table 1 below.

Table 1: The wild plants identified as hosts of Striga gesnerioides in Burkina Faso

\begin{tabular}{|l|l|l|}
\hline $\mathbf{N}^{\circ}$ & Family & Species \\
\hline $\mathbf{1}$ & Convolvulaceae & Ipomoea eriocarpa R. Br. \\
\hline $\mathbf{2}$ & Convolvulaceae & Ipomoea sp \\
\hline $\mathbf{3}$ & Caesalpiniaceae & Cassia mimosoides L. \\
\hline $\mathbf{4}$ & Fabaceae & Alysicarpus ovalifolius (S. Th.) Leon \\
\hline $\mathbf{5}$ & Fabaceae & Tephrosia pedicellata Bak \\
\hline
\end{tabular}


Cassia mimosoides was found in Gaoua parasitized by Striga gesnerioides. Alysicarpus ovalifolius and Ipomea eriocarpa were observed in Thiou parasitized by Striga gesnerioides. At Seytenga, Striga gesnerioides was observed parasitizing Ipomea sp. Thephrosia pedicellata was seen in Gaoua and Dano parasitized by Striga gesnerioides. Photos 3, 4, 5, 6 and 7 below illustrate the wild hosts of the Striga gesnerioides identified during the collection survey.

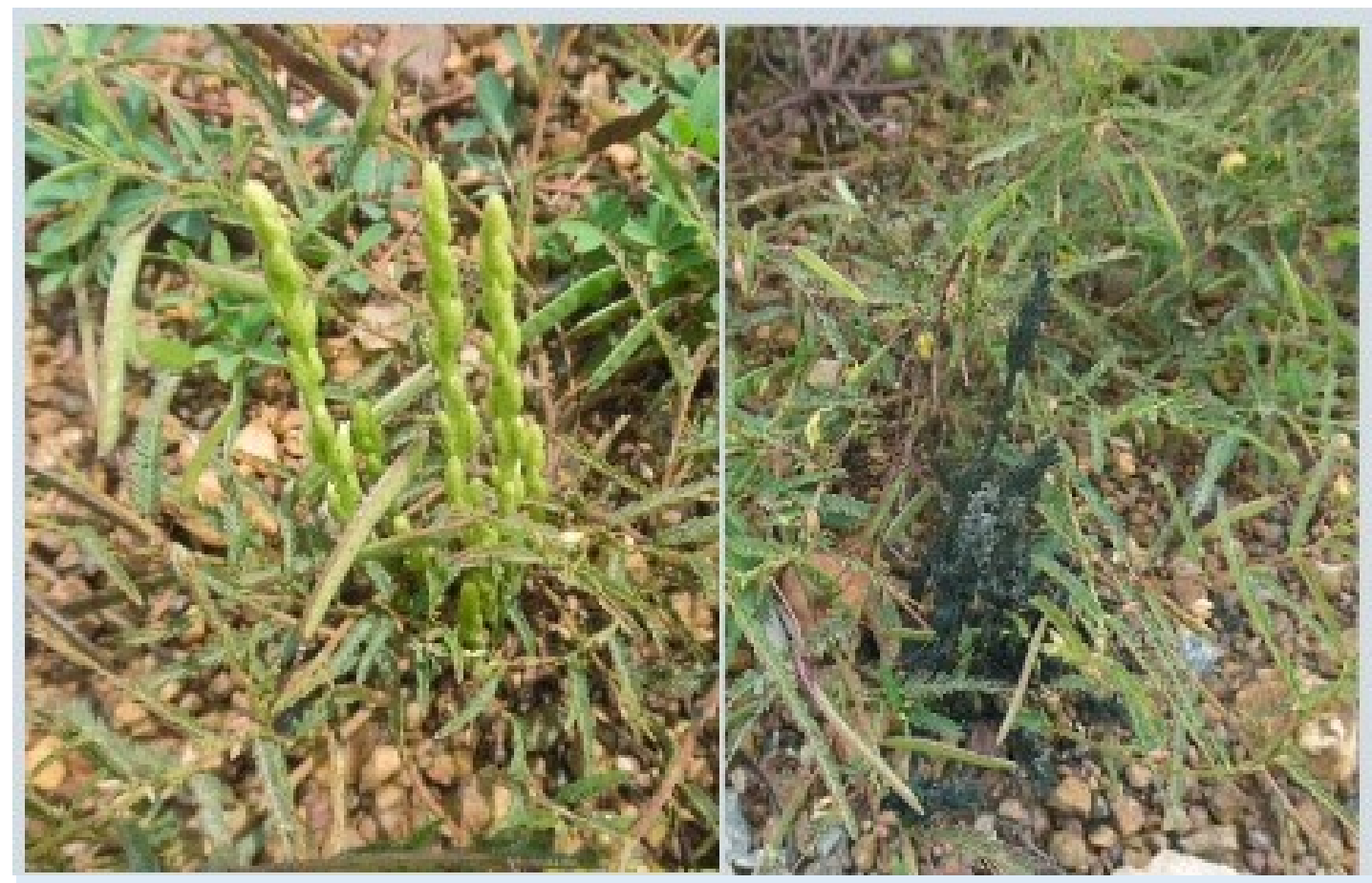

Photo 3: Cassia mimosoides parasitized by Striga gesnerioides 


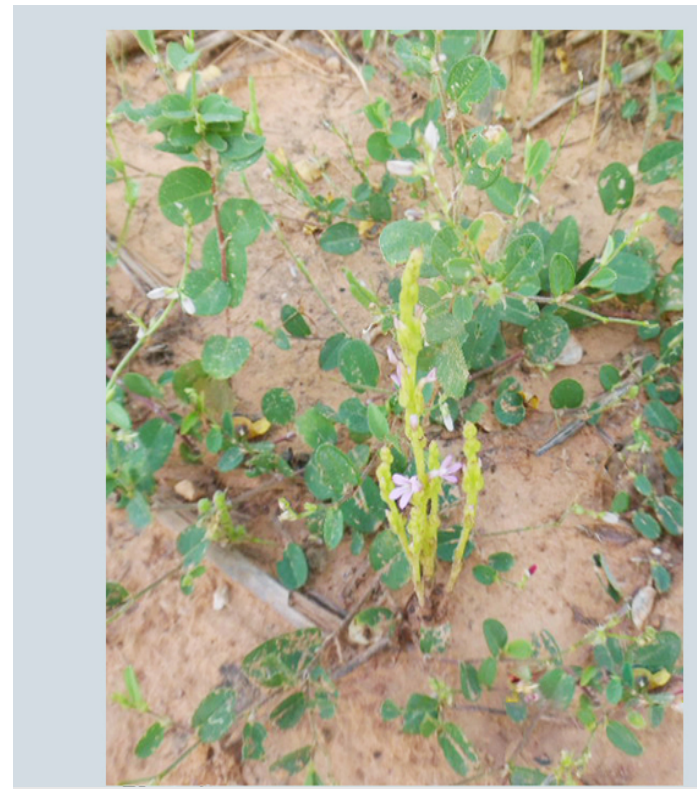

Photo 4: Alysicarpus ovalifolius parasitized by Striga gesnerioides.

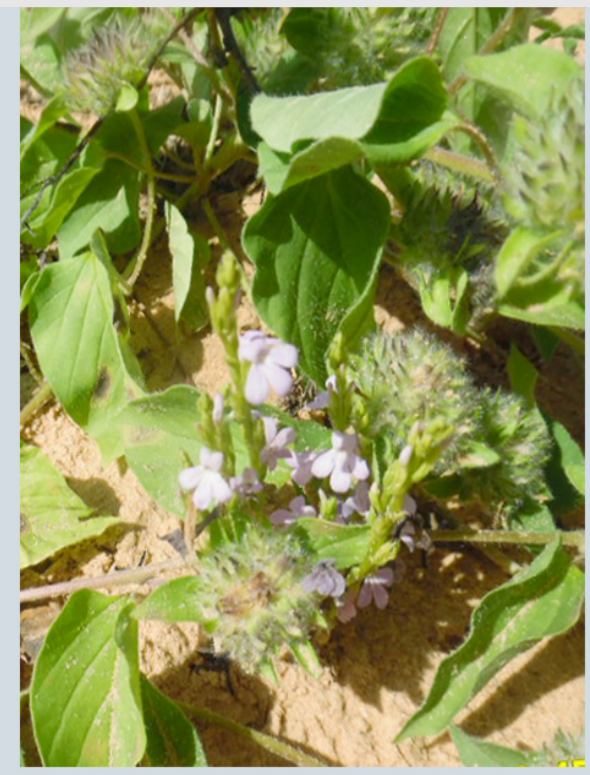

Photo 6: Ipomoea sp. parasitized by Striga gesnerioides

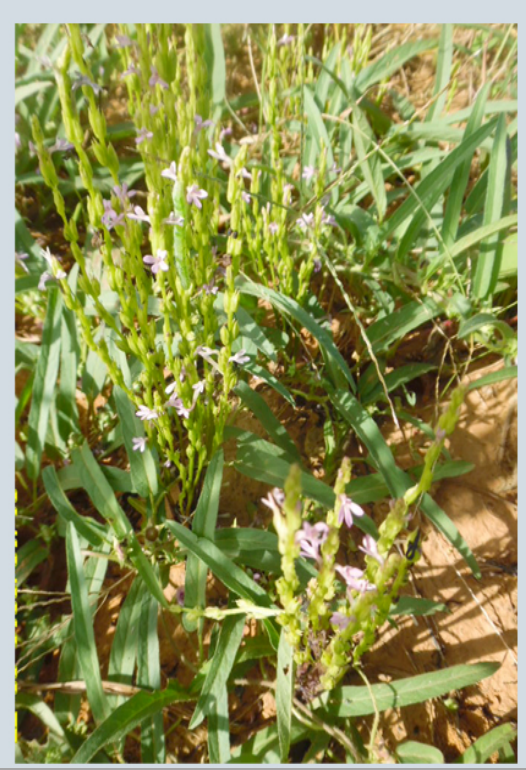

Photo 5: Ipomea eriocarpa. Parasitized by Striga gesnerioides

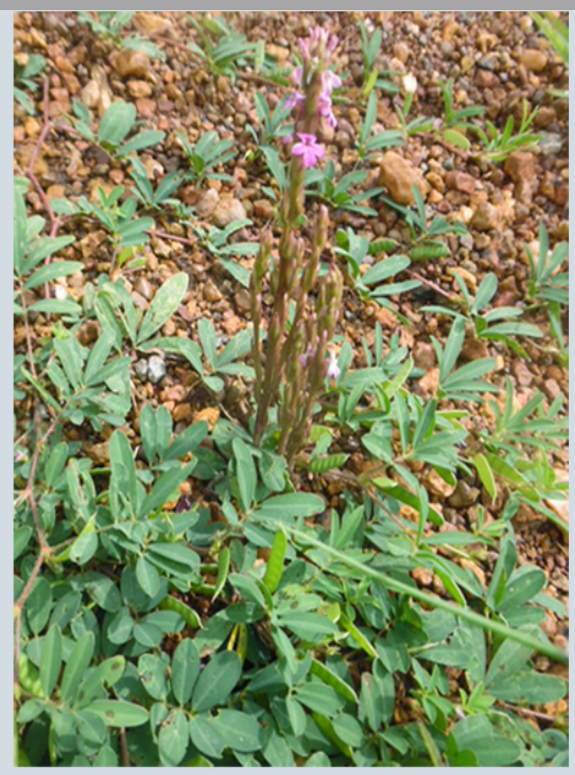

Photo 7: Tephrosia pedicellata parasitized by Striga gesnerioides 


\section{DISCUSSION}

The data collected from the transect work served to establish the geographical distribution map of Striga gesnerioides in Burkina Faso. The results revealed that Striga gesnerioides occurs in almost everywhere in the country. Similar results were reported by (Boussim et al., 2011). However, the observed degree of infestation decreased gradually from Seytenga (Séno) to Niangoloko (Comoé). (Thiombiano et al., 2012) showed that the habitat of Striga gesnerioides includes savannahs, fields and dunes. In addition, the degree of infestation of Striga gesnerioides in Burkina Faso is decreasing from north to south. This observation was made during field visits on the Seytenga transect in Niangoloko. The dissemination of Striga gesnerioides in Burkina Faso followed the climatic gradient from north to south. This is explained by the pressure exerted on the rural land and especially the impoverishment of the cultivable grounds. This has led to and is still causing a gradual shift of farmers from North to South in search of good land for their crops. Those latter, moving with their seeds and their animals, inadvertently contributed to the infestation of the new reception areas. In Cote d'Ivoire the north-south spread of Striga species was reported (Kouakou et al., 2015). In addition to human activities, Striga seed disseminate through water, wind and animals. (Berner et al., 1994, Singh and Emechebe, 1997). The study shows that the spread and degree of infestation of crops by the Striga gesnerioides is much more related to soil poverty than to the amount of rainfall received by the soil. For example, the provinces of the Sissili, Nahouri, Mouhoun, Poni and the locality of Bama in Houet province receive a large amount of rainfall annually, but are characterized by a strong pressure of infestation in the fields by the Striga gesnerioides. That explain because these provinces concentrate a large number of agricultural producers; which makes it impossible to practice fallow that should allow soil restoration. In addition to the galloping demography, the pressure on farmland is increasing and farmers are forced to practice monoculture. The continued practice of leguminous monoculture, the preferred host of Striga gesnerioides, is a factor favouring its expansion. Previous studies have shown that the use of fertilizer reduced field infestation by Striga. The Striga gesnerioides is sometimes associated with desertification, with bush fires causing a sharp reduction in vegetation overcast; aggravated by increasing pressure on arable land (Thalouarn et Fer, 1993, Sallé et al 1995, Singh and Emechebe 1997,
Muleba et al. 1997; Husson et al., 2008). The idea of a recent soil infestation by the Striga gesnerioides in western of Burkina Faso is evidenced by the presence of these on coarse-textured and lateritic soils, as is the case in Dano, Gaoua, Kampti, Toussiana, Niangoloko. In fact, rocky and coarse-textured soils are susceptible to leaching and deplete faster than fine-textured soils (Wade, 2000). The presence of Striga gesnerioides in the southern Sudanian zone, particularly Toussiana and Niangoloko, can be explained in several ways. One of the first factors would be related to decrease of soil fertility and the second to the progressive establishment of cowpea production, privileged host of Striga gesnerioides. The increased of cowpea production facilitates the spread of the parasite (Wade, 2000). The Sahelian regions and the northern Sudanian zones of Burkina Faso are characterized by a strong presence of Striga gesnerioides in the fields. Indeed, the highest infestation densities were observed on coarse, sandy and sandy-loam soils. Similar observations have been made by Traoré and Yonli (2001) and (Boussim et al., 2011) on the other Striga species. However, in Niangoloko even though Striga gesnerioides was observed on cowpea fields, the degree of infestation was negligible to cause serious damage on the host crop. In terms of morphological diversity, four morphotypes were identified. All these morphotypes parasitized cowpea but to different degrees. The most common observed on the cowpea plants was the one with variegated stem and purple-white flowers. Striga gesnerioides plants developed on cowpea was densely branched and more floriferous compared to that observed on alternative wild hosts. Our observations revealed that all identified morphotypes parasitize the cowpea. Our results contradict those of (Parker and Reid, 1979) quoted by (Bâ, 1983) who admits that the morphotype with white flowers is observed only on the cowpea whereas it was observed in Dano and Gaoua on Theprosia pedicellata (see photo 7 above), wild host. This study results are different from those of (Pieterse and Verkleij, 1991) who identified four main morphotypes parasitizing different hosts and Boussim, 2002, which identified three main morphotypes also parasitizing different hosts. The findings of this study are in agreement with the results of (Wade, 2000) who, by screening the seeds of Striga gesnerioides harvested from wild hosts, found that these seeds germinated and grew normally on cowpea. In addition to cowpea, five species have been identified as alternative wild hosts of Striga gesnerioides in Burkina 
Faso. Some of these species were also identified by CONCLUSION AND APPLICATION OF RESULTS

The geographical distribution map established from this study showed that Striga gesnerioides occurs in all four phytogeographic sectors of Burkina Faso, but its preferred areas are the northern Sahelian, southern Sahelian and northern Sudan. . In addition, four (04) morphotypes of Striga gesnerioides were identified.

\section{ACKNOWLEDGEMENTS}

We would like to thank "Université Joseph KI-ZERBO" for accepting our thesis registration. At the same time, we would like to thank INERA for accepting us as a trainee at the experimental station (CREAF) in

\section{REFERENCES}

Bâ AT, 1983. Biologie du parasitisme chez deux Scrophulariacées parasites: Striga hermonthica (Del.) Benth. et Striga gesnerioides (Wild.) Vatke. Thèse de doctorat d'Etat, Université de Dakar, $139 \mathrm{p}$.

Bebawi FF, 1987. Cultural practices in witchweed management. Dans Parasitic weeds in agriculture. Vol. 1. Striga. Éditeur: L.J. Musselman. CRC Press Inc., Boca Raton, Fla. pp. 159-171.

Berner DK and Williams OA, 1998. Germination stimulation of Striga gesnerioides seeds by hosts and non-hosts. Plant Disease 82(11): 1242-1247.

Berner DK, Cardwell KF, Faturoti BO, Ikie FO, Williams OA, 1994. Relative roles of wind, crop seeds, and cattle in dispersal of Striga spp. Plant Dis. 78: 402-406.

Boussim IJ, 2002. Les Phanérogames parasites du Burkina Faso: inventaire, taxonomie, écologie et quelques aspects de leur biologie. Cas particulier des Loranthaceae parasites du karité. Thèse Doctorat d'état ès Sciences Naturelles, Université de Ouagadougou. 285p.

Boussim IJ, Yonli D, Guinko S, Sallé G, 2011. Etat d'infestation, connaissance endogène et approche systématique des espèces du genre Striga au Burkina Faso Int. J. Biol. Chem. Sci. 5(4): 1374-1386

Botanga CJ and Timko MP, 2005. Genetic structure and analysis of host and non-host interactions of Striga gesnerioides (Witchweed) from Central Florida. Phytopathology 95 (10):11661173.
(Boussim et al., 2011)

These morphotyes parasitize five (05) alternative wild hosts in addition to cowpea. A molecular characterization could allow better understanding the intraspecific variability of Striga gesnerioides in Burkina Faso for the sake of develop new strategies in breeding for cowpea resistance to Striga gesnerioides.

Kamboinsé. We also express our gratitude to Kirkhouse Trust SCIO, TLIII, IITA and Bayer for facilitating this work with financial support.

Hibberd, JM, Quick WP, Press MC, Scholes JD, 1996. The influence of the parasitic angiosperm Striga gesnerioides on the growth and photosynthesis of its host, Vigna unguiculata. Journal of Experimental Botany 47: 507-512.

Hoffman G, Diarra C, Dembélé IB, 1997. Dossier Striga. - in Agriculture et Développement, $\mathrm{n}^{\circ}$ 19. Revue trimestriel ISSN 1249-9951. p3047

Husson $\mathrm{O}$, Michellon $\mathrm{R}$, Charpentier $\mathrm{H}$, Razanamparany C, Moussa N, Naudin K, Razafintsalama $\mathrm{H}$, Rakotoarinivo $\mathrm{C}$, Andrianaivo AP, Rakotondramanana, Seguy L, 2008. Le contrôle du striga par les systèmes SCV (Semis direct sur Couverture Végétale permanente). Principes et interets des SCV: contrôle des pestes végétales. Manuel pratique du semis direct à Madagascar, 20p

Ibrahim B, Polcher J, Karambiri H, Rockel B, 2012. Characterization of the rainy season in Burkina Faso and it's representation by regional climates models. Climate Dynamics $39: 1287$ 1302

IFOAM, 2007. Manuel de formation de l'IFOAM sur l'agriculture biologique dans les pays tropicaux. $215 \mathrm{p}$.

INSD., 2009. Annuaire statistique 2010.www.insd.bf consulted in december 2018

Kouakou CK, Akanvou L, Zoro Bi IA, Akanvou R, N'da HA, 2015. Distribution des espèces de Striga et infestation des cultures céréalières dans le nord de la Côte d'Ivoire. Cah Agric 24: 37-46

Koga C, Mabasa S, Mazarura U, Banwa T, Garwe D, 2018. Screening of Tobacco Genotypes for Tolerance/Resistance to Striga gesnerioides 
infestation in Zimbabwe. Adv Crop Sci Tech 6: $340.3 p$

Koga C, Mabasa S, Mazarura U, Garwe D, Rukuni D, 2017. First Reports of Tobacco Witch Weed (Striga gesnerioides) Parasitizing Dalbergia melanoxylon and Richardia scabra in Zimbabwe. Adv Crop Sci Tech 5: 311. 2p

Langyintuo $S A$, Lowemberg-Deboer J, Faye $M$, Lambert D, Ibro G, Moussa B, Kergna A, Kushwaha S, Musa S, Ntoukam G, 2003. Cowpea supply and demand in West and Central Africa, Field Crops Research, no.82, p. 2215-2231.

Muleba N, Ouédraogo JT, Tignegré JB, 1997. Cowpea yield losses attributed to Striga infestations. J. Agr. Sci. 129: 43-48.

Ouédraogo TJ, 2001. Construction d'une carte de liaison génétique du niébé (Vigna unguiculata (L.) Walp.) et identification de marqueurs AFLP liés aux gènes de résistance au Striga gesnerioides (Willd.) Vatke. Thèse de doctorat $(\mathrm{PhD})$ université de Laval Quebec.151p.

Ouédraogo TJ, Ouédraogo M, Gowda SB, Timko MP, 2012. Development of sequence characterized amplified region (SCAR) markers linked to race-specific resistance to Striga gesnerioides in cowpea (Vigna unguiculata L.). African Journal of Biotechnology Vol. 11(62), 1255512562

Parker C, 1991. Protection of crops against parasitic weeds. Crop Prot. 10: 6-22.

Pieterse AH and Verkleij JAC, 1991. Genetic variability in Orobanche (broomrape) and Striga (witchweed) and its implication for host crop resistance breeding. In J. Rozema et J.A.C. Verkleij (Éds). Ecological responses to Environmental Stresses, p. 290-302. Kluwer Academic Publishers, Dordrecht, the Netherlands.

Ramaiah KV, Parker C, Vasuaeva RMJ, Musselman LJ, 1983. Manuel d'identification et de lutte contre le Striga. Bulletin d'information $\mathrm{N}^{\circ} 15$. Patancheru, A.P., In: International Crops Research Institute for the Semi-Arid Tropics. $51 \mathrm{p}$.

Raynal-Roques A, 1993. Contribution à la connaissance de la biologie des Striga (Scrophulariaceae): types biologiques et phénologie. Bulletin Museum National Histoire Naturelle, Paris, 4è série, 15, section B, Adansonia, n¹-4: 3-31.
Sallé G, Raynal-Roques A, Tuquet C, 1995. Un fléau en Afrique, les Striga. Vie sci. 12 : 27-46.

Sallé $G$ et Raynal-Roques A, 1989. Le Striga. La Recherche 206: 44-52.

Sallé G, 2002. Des vampires chez les plantes, en guerre contre les plantes parasites, Bulles de sciences, p. 237

Singh BB and Emechebe AM, 1997. Advances in research on cowpea Striga and Alectra. Dans Advances in cowpea research. Éditeurs : B.B. Singh, D.R. Mohan Raj, K.E. Dashiell et L.E.N. Jackai. Co-publication de l'IITA et du JIRCAS. IITA, Ibadan. pp. 215-224.

Thalouarn $\mathrm{P}$ et Fer A, 1993. Le Striga, un ravageur de cultures vivrières: le point sur les connaissances récentes et sur les méthodes de lutte. Cah. agric. 2: 167-182.

Thiombiano A, Schmidt M, Dressler S, Ouédraogo A, Hahn K, 2012. Catalogue des plantes vasculaires du Burkina Faso. BOISSIERA 65, $391 \mathrm{p}$.

Tignegré JBS, 2010. Genetic Study of Cowpea (Vigna unguiculata (L.) Walp Resistance to Striga gesneriodes (Willd.) Vatke) in Burkina Faso. $\mathrm{Ph}$. D. thesis in Plant Breeding, African Centre for Crop Improvement, School of Agricultural Sciences and Agribusiness, Faculty of Science and Agriculture, University of KwaZulu-Natal, Republic of South Africa, 170p.

Traoré H et Yonli D, 2001. Striga et autres adventices: perception paysanne et inventaire des méthodes endogènes de lutte dans l'Est du Burkina Faso. Science et Technique, Sciences Naturelles et Agronomie, 25(1): 46-59.

Wade M, 2000. Striga gesnerioides (Willd) Vatke parasite du niébé dans le bassin arachidier du Senegal: Situation actuelle et perspectives de lutte: synthèse des travaux menés sur Striga gesnerioides de 1987 à 1998.

Zoungrana I, 1991. Recherches sur les aires pâturées du Burkina Faso. Thèse d'Etat, Université de Bordeaux III, UFR Aménagement et Ressources Naturelles, $277 \mathrm{p}$. 